\title{
English Teachers' Professional Development: Perspectives From Canada, Saudi Arabia, and Pakistan
}

\author{
Mohammed S. Al-Harbi \\ English Language Institute, King Abdul-Aziz University Jeddah, Kingdom of Saudi Arabia \\ Hussain Ahmad \\ English Language Institute, King Abdul-Aziz University Jeddah, Kingdom of Saudi Arabia
}

\begin{abstract}
English teacher professional development (PD) follows different pathways in different contexts depending on local classroom ecology; however, the main goal of PD is to improve learners' academic achievements. For this purpose, the current study provides a comparative analysis of Teaching of English to the Speakers of Other Languages (TESOL) teacher professional development perspectives from Canada, Saudi Arabia, and Pakistan. Data was collected from seven teachers who had EFL/ESL teaching experience in Canada, Saudi Arabia and Pakistan. The study attempted to find out dominant English teacher professional development pathways in the three contexts and investigated how these pathways influence teacher classroom practices.
\end{abstract}

Index Terms-English teacher professional development, cross-cultural perspectives, ESL/EFL classroom practices

\section{INTRODUCTION}

Teacher preparation programs follow almost identical syllabi everywhere since the aim of preparatory teacher programs is to equip graduates with a theoretical repertoire in the field. Teacher professional development (PD) programs aim to prepare in-service teachers for context-specific challenges. Therefore, PD programs do not follow a linear path like teacher education programs, but rather have a complex organization due to multiple theoretical and pedagogical factors. In other words, teacher professional development is always context-driven (Borko et al., 2010). Teacher professional development initiatives are influenced by socio-cultural factors, political thoughts and religious ideologies, teaching and learning aims, and classroom pedagogies. Hence, teacher professional development is always a customized approach in different teaching contexts. Particularly, English as a second language (ESL) and English as a Foreign language (EFL) professional development is designed and implemented based on the local classroom realities. The school-based PD incorporates the contextual teaching practices as it is rooted in students' and institution's needs as well as in teachers' own classroom pedagogies. Against this backdrop, in this article we will present a comparative analysis of EFL/ESL teacher professional development approaches in Canada, Saudi Arabia, and Pakistan.

To begin with, English language teaching in Canada mainly focuses on the immigrant population whose first language is not English. The main goal of English Language Teaching (ELT) programs therefore is to enable the learners to acquire English language competency for professional or academic purposes. Moreover, English language learners acquire the language as a second language. For this reason, the teaching approaches and methodologies are in line with ESL pedagogies. Whereas, in Saudi Arabia and Pakistan, English is taught and spoken as a foreign language mainly for academic rather than communication purposes. However, English is playing different academic and communicative functions in both countries due to the different histories and socio-political conditions.

Being a former British colony, Pakistan has adopted English as an official language (Kasi, 2010). So, English is considered a vehicle for upward social mobility and career enhancement. English language is more important than the national language, which is Urdu, for those who want to go up higher in higher education and have access to prestigious public jobs. Moreover, all academic subjects including history, sociology, sciences, medicine, and engineering are taught in English. Hence, the learners are expected to have a high level of English proficiency. For this reason, some scholars believe that English language in Pakistan has more a second than a foreign language status (Rahman, 2001). On the other hand, in Saudi Arabia, English language is used mainly for academic purposes as a subject in educational institutes, while all other subjects are taught in Arabic. Those students who aspire to higher education abroad learn advanced levels of English. Therefore, EFL/ESL teacher professional development approaches are made and implemented differently in Canada, Saudi Arabia, and Pakistan.

Hence, the objective of the current study is to investigate perceptions of TESOL teachers who taught in Canada, Saudi Arabia, and Pakistan regarding their professional development in the three contexts. The following overarching 
research question is addressed in this study: What are major TESOL teacher professional development pathways in Canada, Saudi Arabia, and Pakistan? And how they impact teachers' classroom practices?

\section{LITERATURE REVIEW}

In the following section, we will review how English teaching is viewed in the three countries and how English teacher professional development is designed and applied in the three different language teaching traditions and contexts.

\section{A. An Overview of ESLEFL Teacher Professional Development in the Three Countries}

Like most classroom pedagogies in developed nations, Canadian ESL teaching is driven by the notion of studentcenteredness. Expectations from teachers are that they bring about change in student learning outcomes by providing a congenial learning environment where learning is co-constructed and teaching and learning occur naturally. Moreover, due to the egalitarian outlook of the society, classroom practices are dominated by the concept of hearing students' voices (Han, 2016). These teaching norms demand an ESL teacher to have acquired the latest knowledge and expertise in the field of English language teaching (ELT). As Canadian ESL teachers are always intrinsically motivated to take part in self-driven professional development initiatives, they strive to find ways to develop their teaching practices as well as the student learning outcomes. In addition to self-driven professional development, Canadian English language teaching institutes encourage faculty members to participate in professional workshops and programs that enhance their teaching skills. Finally, Canadian ESL teachers are motivated to get enrolled in higher education programs to develop their teaching repertoire as well as to create opportunities for better future career opportunities.

In Saudi Arabia, English language teaching is dominated by teacher-centered pedagogies. Teacher-centeredness is in line with the local traditions and cultures which have impacts on teaching and learning English as a Foreign language (Moskovsky \& Picard, 2018). Quite recently, the authorities have realized that classroom teaching should shift from teacher-centered to student-centered approaches to bring learners' written and spoken competency to the global benchmark. For this purpose, local and international teacher training and teacher professional development programs have been conducted at all levels. However, there is a reluctance for egalitarian notions of teaching. This reluctance is both from learners as well as teachers, but the biggest factor is society's perceptions towards learning (Elyas \& Picard, 2019). Studies have shown that such programs have had little impact on teachers' classroom practices and student learning outcomes (Al-Asmari, 2016). One of the reasons for this failure is that professional development programs have been exported from other EFL contexts which do not meet the local expectations. Moreover, in this conservative culture teacher is considered a fountain of knowledge who transmits knowledge to students; whereas, in the Canadian teaching traditions teaching is socio-culturally constructed between teachers and students and between materials and culture.

As mentioned earlier, English language teaching has a different status in Pakistan owing to the role of English in society, and the country's colonial legacy. As compared to English teaching in Canada and Saudi Arabia, in Pakistan English is an official language and therefore there are blurry boundaries between EFL and ESL. As for English language teaching, all educational institutions are dependent on grammar translation methodologies (Al-Mohanna, 2010). Moreover, in English departments, English language is taught through English and American literature which develops students' written communication which is a much-needed skill for passing public exams. Since English is not used for oral communicative purposes, spoken English is given a scant attention. When I left Pakistan for the first time and joined an English language institute in Saudi Arabia, my spoken language was replete with vocabulary and structure that I had learned from reading English literature. While communicating with colleagues from diverse linguistic and socio-cultural backgrounds, I had to unlearn the classical language. Against this backdrop, English language teachers' professional development in Pakistan is still a hazy concept. A couple of years ago, government initiatives focused on hiring international organizations such as British council for delivering professional development programs. These programs delivered ready-made materials rather than designing cultural-specific materials for the local consumptions. Therefore, these teacher professional development programs have had little impact on real teacher classroom practices (Akram, et al. 2020). Despite no or little organizational support for EFL teacher professional development, teachers are involved in self-driven professional development activities to enhance their professional careers. This will be explained further in the sections to follow. Also, in the section that follows, ESL/EFL teacher professional development approaches, models, and challenges will be discussed in relation to Canada, Saudi Arabia, and Pakistan.

\section{ESL Teacher Professional Development Approaches in Canada}

ESL teacher professional development approaches in Canada mainly adhere to the notion of self-development via self-driven initiatives. These include teachers' involvement in reflective practices, reading of current research-informed publications, action research, communities of practice, and professional learning communities. Engagement in such programs is driven by individuals' needs and needs analysis.

Self-reflection as a professional development enables English language educators to reflect on their classroom practices as well as on their growth as a teacher. In the Canadian ESL context, this mode of professional growth is 
popular among teachers because it allows them to have an in-depth analysis of their teaching beliefs and teacher professional identity. Among the reflective practices that ESL educators use for self-development are critical autoethnography narratives (Yazan, 2018). Autoethnography is a powerful way of aligning practices with pedagogy (Canagarajah, 2012). As a professional development pathway, autoethnography not only enhances teachers' classroom repertoire but also teacher agency in designing and implementing their professional learning trajectories and their teaching methods and approaches that suit their students and the overall socio-cultural context of the classroom. In the Canadian ESL context, studies have shown that English language educators also use journal writing as a reflective practice. For example, Farrell (2013) investigated that how an ESL college teacher in Canada improved her reflective practices through journal writing. The results of the two years of reflection showed that the participant improved her awareness as a teacher and that her professional behavior changed inside and outside the classroom. Teacher professional identity development is a dominant theme in teacher professional development (Beauchamp, \& Thomas, 2009). In contrast, in the Saudi EFL context studies have shown that EFL teachers' professional identity development crisis negatively impacts student learning outcomes (Mansory, 2019); but unlike in Canadian context, in the Saudi EFL teaching context researchers have suggested that formal teacher professional development programs such as in-services PD initiatives should consider teacher professional identity development as the main goal. Whereas, in the Canadian ESL context, researchers believe that self-directed teacher reflection is a way for enhancing teacher identity (Yazan, 2018).

Next, reading current research-informed publications is another way of professional development for ESL teachers in Canada. Studies have shown that K-12 English language teachers in many Canadian provinces improve their classroom practices through reading professional literature to foster more effective learning and to facilitate their academic success (Abbott et al., 2017). Reading professional literature for improving classroom practices and student learning outcomes is effective only if the practices are localized and contextualized according to the learners' level and learning styles as well as the institutions' agenda or curricula. Although enhancing classroom pedagogy and teaching repertoire through reading published articles is a proven pathway for teacher professional learning, in the ESOL field teachers have been tasked with adhering to the latest trends and publications regardless of their applicability (Nation \& Macalister, 2010) Therefore, action research is a probably a better channel for teacher professional development.

Action research was conducted by teachers to gain insight and develop their reflective and classroom practices that positively enhance their English learners' academic achievements. Mills (2007) describes that action research is "any systematic inquiry conducted by teacher researchers, principals, school counselors, or other stakeholders in the teaching/learning environment to gather information about how their particular schools operate, how they teach, and how well their students learn" (p. 5). Studies in the Canadian K-12 ESOL context (Herrera, 2018) have shown that action research has multiple benefits for the learners, teachers, and institutes.

In addition, in the Canadian English language teaching context, ESOL teachers utilize professional communities as a tool for their continuous professional development. These communities have been categorized in communities of practice (Wenger, 1998) and professional learning communities (Dufour, 2002). Communities of practice involve "groups of people who share a concern, a set of problems, or a passion about a topic, and who deepen their knowledge and expertise in this area by interacting on an ongoing basis" (Wenger et al., 2002, p.4). These are formalized and structured groups but without an institutional mandate. In Canadian universities, communities of practice have provided teachers and researchers platforms for researchers and teachers to develop a shared repertoire of knowledge and practices wherein newcomers as well as veteran faculty members engaged in collaborative work (Gallagher et al., 201; Griffiths et al., 2010). Kosnik et al. (2015) have also found that communities of language teacher educators in Canada have yielded positive results for teachers and institutions. Nevertheless, as compared to the loose structure and voluntary participation in communities of practice, professional learning communities that are mandated by formal institutional structure foster better teacher collaboration in the Canadian ESL context (Abbo et al., 2018).

\section{EFL Teacher Professional Development Approaches in the Kingdom of Saudi Arabia}

As mentioned earlier, the Saudi EFL context is different from other EFL contexts around the world. The EFL teacher professional development approaches and methods have to be different in line with the local learning and teaching traditions and societal expectations. Unfortunately, very little attention is given to developing English teachers' professional development in this context (Al-Seghayer, 2014). In the preceding paragraphs, we have illustrated the reasons for the uniqueness of English teaching. In this section, first, we will describe the most popular Saudi EFL teacher professional development pathways and then we will present a brief analysis of the overall EFL teachers' professional development.

With the advent of Saudi Vision 2030, the Saudi government has initiated several EFL teacher professional development programs to improve students' proficiency in both oral and spoken English. For this purpose, many formal and informal professional development programs were implemented at primary, secondary, tertiary, and higher levels. Formal programs are government-led that mostly comprise teacher training to novice and in-service experienced EFL teachers by foreign professional bodies such as the British council, NILE, Cambridge Assessment, and Pearson. Research indicated that these programs failed to achieve the desired goals (Mansory, 2019). The teachers resist shifting their methodological approaches from traditional to modern ones due to internal and external factors. The internal factors include teachers' own English learning background in grammar-translation method and hence their reluctance to 
acquire and practice communicative language teaching techniques. Moreover, stringent institutional policies hinder teachers' freedom to teach according to what they learn in professional development programs (Ahmad et al., 2018). Nevertheless, the external factors are no less responsible for the teachers' failure to teach well. The foremost difficulty in translating professional development into classroom practices is the mismatch between the content and pedagogy of the teacher training or professional development programs and the local classroom realities. The PD programs developed and tested in democratic societies in the West and far East hardly work in the conservative and religious culture of the Arabian Gulf.

In addition to formal PD programs, classroom observations are another EFL teacher professional development tool in Saudi Arabian higher education institutes. To improve EFL teachers' classroom performance institutes conduct professional classroom observations. It is noteworthy that the English Language Institute (ELI) is the first and probably the only English language teaching organization that have a structured teacher observation program. Being classroom observers in this institute, we can describe how classroom observations serve as a PD tool. Teacher classroom observations are divided into three categories: diagnostic observation, formal observation, and follow-up unannounced observation. Each teacher is observed during the first term to diagnose his teaching practices. After the first visit, he is advised on the areas to work on before the next formal observation visit. The formal observation visit is intended to see a cross-section of teachers' classroom practices including methodology and classroom management. Then postobservation feedback is conducted to discuss with the teacher the areas that he is good in and the areas that he should work on. Finally, at the follow-up observation stage, observers see if the teacher maintains his grade given at the formal observation. Based on my experience as a professional classroom observer, teachers improve their classroom practice as a result of the rigorous process. Although they do not adhere to the best practices around the year due to institutional constraints, they mostly practice good methods and approaches as much as possible. Nevertheless, researchers have shown that classroom observations do not achieve the desired results due to time constraints, other studies have indicated otherwise (e.g., Shah et al., 2003).

Saudi EFL teachers also utilize other professional development avenues in addition to the aforementioned ones. For example, reflective practices are becoming popular after the education modernization efforts (Sibahi, 2015). This study explored how reflective practices fail to enhance EFL teacher professional development. The results of this study indicated that the participants were aware of the importance of reflection in terms of their classroom practices and that they employed different tools for reflection. Nevertheless, the following impeding factors have been reported: uncertainties regarding reflective practices, fixed curricula, and lack of training in reflective practices.

\section{EFL Teacher Professional Development Approaches in Pakistan}

In this section, we will present the historical background to English language teaching in Pakistan, modes, and approaches to teachers of English professional development, professional development institutes, and challenges.

Since British colonial rule (1608-1857) in the Indian sub-continent, the English language has been enjoying a privileged status in all social and economic fields such as administration, judiciary, military, education, trade, and mass communication. A little number of westernized Pakistanis speak English as a first language, some educated or highly educated people speak it as their second language, and most educated people use it as a foreign language (Rahman, 2001). The status of English in Pakistan, therefore, is distinguished from the role it plays in Canada and Saudi Arabia: in the former people speak it as a first language while in the latter people use it as a foreign language. However, like in Saudi Arabia, in Pakistan English teaching follows the traditional transmission teaching model wherein teachers concentrate on doing a lesson irrespective of the class size and learners' learning styles. Studies (e.g. Kasi, 2010) have shown that professional development of teachers of English is carried out in a manner that rarely meets teachers' teaching needs.

Like the knowledge transmission teaching approaches, EFL teacher professional development follows top-down approaches in Pakistan. Content and pedagogy of professional development programs are imposed by the higher administration rather than designed by teachers (Khan \& Afridi, 2017). One of the salient features of top-down PD is that one-shot sessions or a small series of workshops or training sessions are conducted, and teachers are expected to know the theoretical knowledge of the subject only. In other words, the training and PD materials and methods are ready-made and lack tailor-made solutions for the contextual issues. The transaction model of dissemination of knowledge is the reflection of the overall teaching and learning traditions and beliefs in the developing world (Dayoub \& Bashiruddin, 2012).

Many public and private teacher professional development initiatives have been seen in the past two decades. These include pre-service as well as in-service programs by international institutions like The British Council of Pakistan (BCP), United States Educational Foundations in Pakistan (USEFP), and United States Agency for International Development in Pakistan (USAID-Pakistan). In addition, local institutes and organizations have also conducted preservice teacher training and in-service professional development programs. These institutes include the Higher Education Commission of Pakistan (HEC), Institute of Educational Development at Aga Khan University Karachi (IED-AKU), Society of Pakistani English Teachers (SPELT), TEFL short and long courses by Allama Iqbal Open University (AIOU). However, according to Kasi (2010), almost all of the above-mentioned programs have no impact on teachers' professional learning and student learning outcomes. 
Teacher professional development initiatives in Pakistan have failed to yield the intended results due to many reasons. Firstly, the teacher professional development programs are conducted in a top-down manner utilizing traditional approaches of knowledge transmission (Kasi, 2010). Secondly, teachers and teacher trainers are not provided adequate resources and time (Khattak et al., 2011). Teachers usually are unable to have time for participation in training or professional development programs because of heavy workload and social responsibilities. Moreover, participation in any professional development activities outside the regular work is not rewarded in the forms of academic credits, salary increase, or promotion. Thirdly, EFL teachers rarely get professional support from more experienced peers in their own organizations or from university researchers (Chaudary \& Imran, 2012). Finally, due to the above-mentioned hindering factors and other socio-cultural impediments, teachers have no personal drive for enhancing their professional knowledge and hence students' academic achievement (Khan \& Afridi, 2017).

\section{METHODOLOGY}

\section{A. Participants}

Seven English as a Foreign Language (EFL) teachers from three Saudi Arabian public universities were interviewed. Six EFL teachers were Pakistani-Canadians serving in preparatory year programs of Saudi universities. They had English teaching experience in the three countries. One participant was Canadian born who taught English in Canada and Saudi Arabia. The participants' demographic profiles are given in Table 1. To fulfill the ethical requirements of confidentiality, the researchers maintained the anonymity of the participants by referring to their pseudonyms.

TABLE 1

DEMOGRAPHIC INFORMATION OF THE PARTICIPANTS

\begin{tabular}{|c|c|c|c|c|}
\hline Pseudonym & Nationality & Academic qualification & $\begin{array}{l}\text { EFL/ESL } \\
\text { teaching } \\
\text { experience }\end{array}$ & $\begin{array}{l}\text { Length of stay in } \\
\text { Saudi Arabia }\end{array}$ \\
\hline Tim & Canadian & MA Applied Linguistics & 15 years & 7 years \\
\hline Khan & $\begin{array}{l}\text { Pakistani } \\
\text { Canadian }\end{array}$ & $\mathrm{PhD}$ in TESOL & 20 years & 10 years \\
\hline Ali & $\begin{array}{l}\text { Pakistani } \\
\text { Canadian }\end{array}$ & MA TEFL & 17 years & 4 years \\
\hline Dawood & $\begin{array}{l}\text { Pakistani } \\
\text { Canadian }\end{array}$ & PhD Language Education & 25 years & 8 years \\
\hline Rashid & $\begin{array}{l}\text { Pakistani } \\
\text { Canadian }\end{array}$ & MA Applied Linguistics & 15 years & 3 years \\
\hline Ahmad & $\begin{array}{l}\text { Pakistani } \\
\text { Canadian }\end{array}$ & MA English Language \& Literature & 27 years & 9 years \\
\hline Tariq & $\begin{array}{l}\text { Pakistani } \\
\text { Canadian }\end{array}$ & MA TESOL & 22 years & 8 years \\
\hline
\end{tabular}

\section{B. Instrument}

To investigate the phenomena of EFL teacher professional development across the three contexts, data was collected using semi-structured interviews. All participants were asked the same questions to increase reliability of the data.

\section{Procedure}

The interviews were conducted online via Google Meet. The participants were sent the interview questions before the interviews. Interviews were recorded and transcribed verbatim. The data analysis was conducted through using Maxqda 2021. The transcribed data was sent to the respondents for member-check. The qualitative data analysis had the following stages which are based on the guidelines given by Creswell (2012) and Saldana (2009):

a. To get a global idea, the transcripts were read thoroughly (Creswell, 2012) to be ready for analysis.

b. Then the transcripts were coded according to the recommendations given by Creswell (2012) and Saldana (2009). A code, according to Saldana (2009) is "is most often a word or short phrase that symbolically assigns a summative, salient, essence-capturing, and/or evocative attribute for a portion of language-based or visual data" (p.3). During the first cycle of coding, the researcher did decoding and encoding (Saldana, 2009); decoding is to extract the core meaning from a data passage, whereas encoding is allocating an appropriate code to the data.

c. A pattern of codes was detected.

d. In the second cycle of coding, similar codes were grouped together.

e. To follow Creswell (2012) and Saldana (2009), after the second cycle codes were subsumed to broad categories.

f. These categories were grouped together in the light of the research question and themes were developed. The researchers made sure that the themes answer the research questions.

\section{FINDINGS}


After analyzing the data, the following categories emerged from the participants' responses regarding the EFL teacher professional development in the three English teaching contexts (Canada, Saudi Arabia, and Pakistan):

\section{A. Reflective Practices}

Participants of the study have a unanimous opinion on the concept that in Pakistani and Saudi Arabia English language teaching institutes view professional development from the traditional lenses and do not apply reflective practices as a teacher professional development tool.

"In Pakistan and Saudi Arabia EFL teachers cling to transmission-oriented teaching paradigm which has or little space for reflective practices; while in Canadian ESL context we develop as teachers mainly through our reflection of our past practices". (Ali)

On the other hand, one participant regarded the Pakistani teachers' teaching philosophy as outdated which does not cater to the modern and emerging student learning needs.

\section{B. Reading a Research-informed Literature}

Most of the participants believe that in Canadian English teaching institutes teachers enhance their skills through reading professional literature. In fact, research in the field is considered authentic and reliable. "In Canada, research is genuine and authentic". (Tim)

In contrast, the participants opined that research practices especially in the field of EFL in Pakistan and Saudi Arabia are sometimes not credible and practical and hence cannot be considered a tool for professional development.

"True, here we don't rely on literature for improving our classroom practices, as the researchers rarely address the issues we face. Instead, we depend on trial-and-error tactics". (Dawood)

Obviously, teachers read articles that are context specific and useful. EFL teachers in Pakistan and Pakistan doubt that research conducted in their contexts paves way for better classroom practices.

In line with research-based practices, respondents revealed that in addition to implementing literature in their classrooms, teachers in Canadian ESL context use action research as a major pathway for their professional development.

\section{Communities of Practice (CoPs) / Professional Learning Communities (PLCs)}

The participants' accounts indicate that contrary to the collaborative teacher learning in Canada, in Pakistan and Saudi Arabia teacher professional development is a solo journey.

"We rarely sit together to discuss what's happening in our classroom or to share materials that could help us and our students". (Ahmad)

On the other hand, participants appreciated the collegiality in Canadian institutes. The institutional culture encourages teachers to learn from each other.

"In Canada, teaching methods especially English language teaching skills get improved through working in professional learning communities and communities of practice" (Khan)

As has been revealed by the participants' narratives, Canadian teaching and learning is influenced by the democratic norms of the society.

\section{EFL Teacher Professional Identity}

Interviewees' responses showed that English teacher professional development approaches in Canada cater not only to the skills related needs but also to the teachers' social and psychological needs.

I'm glad that the Canadian in-service teacher development programs make you feel who you are as a teacher and offer opportunities to locate our professional and personal selves in schools as well as in the society. In turn, you make the teachers feel their worth. (Rashid)

However, the interviewees' responses never indicated that teacher professional development in Pakistan and Saudi Arabia address teacher identity matters.

\section{E. Classroom observations}

The role of teacher classroom observations has been overlooked in Canadian and Pakistani English teaching contexts. However, participants expressed that classroom observations are important sources of their professional development in Saudi context.

"During classroom observation, teachers have a chance to seen teaching other colleagues who are professional teachers. I like that some higher education institutes in Saudi Arabia value classroom observations". (Tariq)

However, the interviews showed that peer-observations are more beneficial than observations conducted by a mentor or academic coordinator.

"I like peer observations as they are more developmental than evaluative". (Khan)

When asked to describe the role that classroom observations play in their professional development, most respondents used descriptors such as: "integral", "vital", "significant", and "key".

\section{F. One-shot Teacher Training Sessions}


While reflecting on their teaching and learning experience from Pakistan, participants pointed out that one-shot training sessions or workshops only focus on theoretical aspects of classroom teaching topics.

"There trainers think that a single session or a series of sessions will bring changes in teachers' performance, while mere theoretical knowledge without contextualizing it is not sufficient". (Ali)

Other participants focused on the need of reflective practices during trainings and workshops.

"I believe in Pakistan and in Saudi Arabia EFL professional development specialists should encourage novice and in-service teachers to reflect on their teachings to know whether the course requirements and student needs are fulfilled". (Khan)

\section{G. Top-down Approaches}

The participants criticized professional development approaches in Pakistan and Saudi Arabia for being imposed and mainly top-down which lack teacher voice and contextual requirements.

"One-size-fits-all formula doesn't work everywhere. EFL trainers should keep in mind what students need in a particular environment and what teachers need to know about their students". (Tariq)

They praised the teacher professional development initiatives in Canada in this regard:

"In Canada, educationists like the teachers to apply methods and materials that serve the students' needs. They care less about the methods popularity. So, we are one step ahead." (Tim).

A more detailed analysis of the interview responses has allowed us to tease out a relational understanding between the teachers' productivity and bottom-up approaches in this regard.

\section{H. Transmission Teaching Model}

The participants believed that the concept of mere knowledge transmission has a significant impact on EFL teacher professional development in Pakistan and Saudi Arabia. Trainers and professional development specialists consider themselves as fountains of knowledge and trainees or teachers as empty vessels.

"In the developing nations, we still believe that trainers or experienced teachers impart knowledge to the viewers; whereas, in Canada everybody learns from their own and others experience." (Dawood)

Teachers lambasted international trainers as well for not paying attention to develop this sense in educators that knowledge is co-constructed.

"They [trainers] should shoulder the responsibility of enlightening the EFL teachers not to rely on others for their own learning and development." (Khan)

\section{Teachers' Being Heavy Worked}

The interviewees presented another side of EFL teachers that hampers their professional development.

"You know, I don't put all the blame on Pakistani teachers for not keeping abreast with global trends in English language education as they have heavy workload." (Ahmad)

Besides, participants reported that teachers in Pakistan have other social responsibilities that do not allow them to invest their time and money in professional development.

Another interviewee highlighted the disease linked with heavy workload. He mentioned: "I try very hard to always balance my well-being, social responsibilities, and work; but the former two does not allow the affordances to do justice with the latter".

\section{DiSCUSSION AND RECOMMENDATIONS}

From the findings, we saw that in Canada dominant ESL/ESOL teacher professional development approaches include teacher self-reflective practices, reading research informed publications, action research, and language educators' communities of practice and professional learning communities. In addition, professional development activities not only develop their classroom practices but also enhance their teacher professional identity. On the other hand, in Saudi Arabia EFL teacher professional development approaches are training in-service teachers by international bodies, and classroom observations. The findings reveal that top-down prescribed teaching practices and transmission teaching models are more favorable options than bottom-up or customized approaches in PD programs. It was shown that transmission teaching models is a corollary of top-down approaches. In Pakistan EFL/ESL teacher professional development is dominated by short one-short training courses by local and international bodies which has resulted in old-fashioned teacher classroom practices such as transmission teaching models. In addition, the findings showed that teachers in Pakistan are heavy worked in conjunction with heavy social responsibilities which allow them little or no time for engaging in professional development. After mapping out the three scenarios, it is imperative to provide suggestions for practice based on the strengths and weaknesses of the three contexts.

Although ESL/ESL teacher professional development in Canada is according to the best international practices in the field, teacher classroom observation seems to have been given little attention. Therefore, Canadian higher education may incorporate classroom observation element and a follow up feedback in the teacher development programs. The experience of King Abdulaziz University Jeddah can be of great value in this regard. 
Similarly, the Saudi EFL field may benefit from the Canadian experience to improve the classroom teaching. For this purpose, teacher self-reflective practices should be part of teacher development portfolio. In addition, teachers should enhance their practice by reading research informed studies of high esteem conducted locally as well as internationally. Also, as was seen in the Canadian context, Saudi EFL teachers should engage in local and global communities of practice and professional learning communities to glocalize their teaching and enhance learners' performance. In addition to introducing innovations, the existing professional development scheme should be reformed by contextualizing the content, pedagogies, and methodologies of the programs delivered by international bodies. Also, like in Canada, action research should be among the leading pathways to teacher professional development. Finally, the newly launched 'Saudi TESOL' by King Abdulaziz University should be used as a platform for orienting EFL teachers to the best practices in the field.

The ESL/EFL teacher PD practices from Canada and Saudi Arabia should be utilized by the Pakistani higher education to develop the growing number of teachers of English. Besides introducing reflective practices, classroom observations, action research, reading professional literature, Pakistan should overhaul the existing teacher professional development framework. The international bodies should conduct a thorough needs analysis of the Pakistani classroom ecology before importing global training material and methods. Furthermore, collaborative action research (CAR), as suggested by Kasi (2010), should be implemented by the HEC. More importantly, the socio-economic conditions of teachers should be improved to make them like developing themselves as well as their learners. As a final note, like in Canada, EFL teacher professional development in Saudi Arabia and Pakistan should focus on teacher identity development (Ahmad et al., 2017).

\section{REFERENCES}

[1] Abbo, M. L., Lee, K. K., \& Rossiter, M. J. (2018). Articles Evaluating the Effectiveness and Functionality of Professional Learning Communities in Adult ESL Programs. 35(2), 1-25.

[2] Abbott, M. L., Lee, K., \& Rossiter, M. J. (2017). Enhancing the impact of evidence-based publications on K-12 ESL teacher practices. Alberta Journal of Educational Research, 63(2), 193-213.

[3] Ahmad, H., Latada, F., Wahab, M. N., Shah, S. R., \& Khan, K. (2017). Exploring the construction of professional selves of non-native EFL teachers at a Saudi Arabian University. Arab World English Journal,8(4), 148-166.

[4] Ahmad, H., Latada, F., Wahab, M. N., Shah, S. R., \& Khan, K. (2018). Shaping professional identity through professional development: A retrospective study of TESOL Professionals. International Journal of English Linguistics, 8(6), 37. doi:10.5539/ijel. v8n6p37

[5] Akram, H., Yang, Y., Ahmad, N., \& Aslam, S. (2020). Factors Contributing Low English Language Literacy in Rural Primary Schools of Karachi, Pakistan. International Journal of English Linguistics, 10(6), 335-346. doi:10.5539/ijel.v10n6p335

[6] Al-Asmari, A. (2016). Continuous professional development of English language teachers: perception and practices. Advances in Language and Literary Studies, 7(3), 117-124. doi: 10.7575/aiac.alls.v.7n.3p.

[7] Al-Mohanna, A. (2010). English language teaching in Saudi Arabian context: how communicatively oriented is it? Journal of King Saud University (Languages and Translation), 22, 69-88.

[8] Al-Seghayer, K. (2014) The actuality, inefficiency, and needs of EFL teacher-preparation programs in Saudi Arabia. International Journal of Applied Linguistics and English Literature, 3(1), 141-151

[9] Beauchamp, C., \& Thomas, L. (2009). Understanding teacher identity: an overview of issues in the literature and implications for teacher education. Cambridge Journal of Education, 39(2), 175-189

[10] Borko, H., Jacobs, J., \& Koellner, K. (2010). Contemporary approaches to teacher professional development. In P. Peterson, E. Baker, \& B. McGaw (Eds.), International encyclopedia of education (pp. 548-556). Oxford, England: Elsevier.

[11] Canagarajah, A. S. (2012). Teacher development in a global profession: An autoethnography. TESOL Quarterly, 46(2): 258279. doi:10.1002/tesq.18.

[12] Chaudary, I. A., \& Imran, S. (2012). Listening to unheard voices: Professional development reforms for Pakistani tertiary teachers. Australian Journal of Teacher Education, 37(2), 88-98. https://doi.org/10.14221/ajte.2012v37n2.8

[13] Creswell, J. W. (2012). Qualitative inquiry and research design: Choosing among five approaches. London: Sage.

[14] Dayoub, R., \& Bashiruddin, A. (2012). Professional Development in Education Exploring English-language teachers' professional development in developing countries : cases from Syria and Pakistan. Professional Development in Education, $38(4), 589-611$.

[15] DuFour, R. (2004). What is a "Professional Learning Community'? Educational Leadership, 61(8), 6-11.

[16] Elyas, T., \& Picard, M. (2019). Cultural and linguistic factors in the Saudi EFL context (Ed.) In C. Moskovsky and M. Picard (Ed.), English as a Foreign Language in Saudi Arabia: New Insights into Teaching and Learning English (pp. 70-84). Routledge, New York.

[17] Farrell, T. S. C. (2013). Teacher self-awareness through journal writing. Reflective Practice, 14(4), 465-471. https://doi.org/10.1080/14623943.2013.806300

[18] Han, I. (2016). Conceptualisation of English teachers' professional identity and comprehension of its dynamics. Teachers and Teaching, 23(5), 549-569. doi:10.1080/13540602.2016.1206525

[19] Herrera, L. J. P. (2018). Action Research as a Tool for Professional Development in the K-12 ELT Classroom. TESL Canada Journal, 35(2), 128-139. https://doi.org/10.18806/tesl.v35i2.1293

[20] Kasi, F. (2010). Collaborative Action Research: An Alternative for EFL Teacher Professional Development in Pakistan. The Asian EFL Journal, 12(3), 98-177.

[21] Khan, M. A., \& Afridi, A. K. (2017). Professional Development of Teachers and its Future Needs. The Dialogue, 12(2), 211288. 
[22] Khattak, Z. I., Abbasi, G., \& Ahmad, A. (2011). Impact analysis of the in-service teacher training programmes of the Testing and Evaluation sub-committee of the ELTR Project in Pakistan. Procedia - Social and Behavioral Sciences, 15, 1479-1483. https://doi.org/10.1016/j.sbspro.2011.03.314

[23] Kosnik, C., Menna, L., Dharamshi, P., Miyata, C., Cleovoulou, Y., \& Beck, C. (2015). Four spheres of knowledge required: an international study of the professional development of literacy/English teacher educators. Journal of Education for Teaching, 41(1), 52-77. https://doi.org/10.1080/02607476.2014.992634

[24] Mansory, M. (2019). The Meaning and Practice of Professionalism of EFL Teachers in the Saudi Context. English Language Teaching, 12(1), 194-203. doi:10.5539/elt.v12n1p194

[25] Mills, G. E. (2007). Action research: A guide for the teacher researcher (3rd ed.). Upper Saddle River, NJ: Pearson.

[26] Moskovsky, C., \& Picard, M. (2018). English as a Foreign Language in Saudi Arabia: New Insights into Teaching and Learning English. Routledge, New York.

[27] Nation, I. S. P., \& Macalister, J. (2010). Language curriculum design. New York, NY: Routledge.

[28] Rahman, T. (1997). The medium of instruction controversy in Pakistan. Journal of Multilingual and Multilingual Development, $18,145-154$.

[29] Saldaña, J. (2009). The coding manual for qualitative researchers. London: Sage Publication.

[30] Sibahi, R. (2015). Exploring Reflective Practice among College EFL Teachers in Saudi Arabia. Arab World English Journal, 6(2), 337-351. https://doi.org/10.24093/awej/vol6no2.26

[31] Shah, S., Hussain, M., \& Nasseef, O. (2013). Factors impacting EFL teaching: Ann exploratory study in the Saudi Arabian context. Arab World English Journal (AWEJ), 4(3), 104-123.

[32] Wenger, E. (1998). Communities of Practice. Cambridge: Cambridge University Press.

[33] Yazan, B. (2018). TESL Teacher Educators' Professional Self-Development, Identity, and Agency. TESL Canada Journal, 35(2), 140-155. https://doi.org/10.18806/tesl.v35i2.1294

Mohammed AlHarbi is an assistant professor of TESOL at the English Language Institute, King Abdul-Aziz University, Jeddah, Saudi Arabia. He was awarded his PhD degree in 2017 in TESOL from the University of Glasgow, United Kingdom. His research and teaching interests revolve around English language teaching approaches and communicative interaction in the EFL classrooms.

Hussain Ahmad is a lecturer in English at King Abdul-Aziz University, Saudi Arabia. He earned PhD in applied linguistics (Language Education) at the Universiti Malaysia Pahang (UMP). He has MA TESOL from the University of Sunderland, UK. His research interests are EFL teacher professional identity, teacher professional development and teacher training. 